\title{
Lower Cretaceous calcareous nannofossils from the Southern Apuseni Mountains, Romania
}

\author{
Ana-Maria VULC ${ }^{*}$ \\ ${ }^{1}$ Department of Geology, „Babeş-Bolyai” University, Kogălniceanu 1, 400084, Cluj Napoca, Romania
}

Received October 2007; accepted September 2008

Available online November 2008

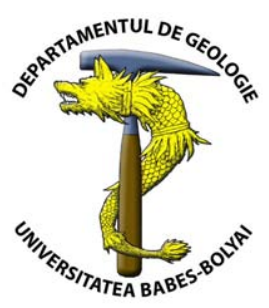

\begin{abstract}
We investigated Lower Cretaceous calcareous nannofossils from Southern Apuseni Mountains. The studied section from Bucium Cerbu quarry is characterized by flysch deposits (rhythmical interbedded marls and sandstones), which were assigned to the Căbești Formation. The studied nannofossil assemblages yielded a high diversity. The Early Aptian age of the studied deposits was assigned based on both the Tethyan and Boreal calcareous nannofossil zonations. Several reworked Valanginian nannofossils were also observed in the Early Aptian in situ nannofloras. The nannofloras are dominated by tethyan and cosmopolitan species. Besides Boreal species are also present. The presence of boreal taxa (e.g., Kokia borealis, K. stelatta) in the Tethyan Realm reflects the palaeobiogeographical distribution and the biotic changes between Tethys and Boreal Realms in the Southern Apuseni Mountains. In the studied assemblages, the dominant species are Diazomatolithus lehmanii and Watznaueria barnesiae, which can reflect a high fertility in the surface water masses.
\end{abstract}

Key words: Lower Cretaceous; biostratigraphy; palaeobiogeography; palaeoecology; Apuseni Mountains, Romania.

\section{INTRODUCTION}

The aim of the present study is to present the Early Cretaceous calcareous nannofossils assemblages identified in the sedimentary rocks of the Bucium Cerbu quarry, as well as to recognize the palaeobiogeographical distribution and the palaeoecological affinities. This is a first attempt to study the calcareous nannofossils in the section of the Bucium Cerbu quarry. Concerning the geological background of the Abrud area, Pálfy (1902) admitted the existence of the Lower Cretaceous deposits south of Abrud.

Other investigations on the Cretaceous stratigraphy of this area belong to Filtsch (1857) and Mücke (1915). Based on a specimen of Lammellaptychus, Ilie (1953) has assigned a Valanginian-Hauterivian age to the deposits. Ianovici et al. (1969) affirmed the wide distribution of the Căbeşti Formation in the Bucium trench, the Barremian age being established on the basis of the superposition relative to the Valea Dosului Formation. Based on the palinological assemblages, Antonescu (1973) established the HauterivianBarremian-Lower Aptian age for the Căbeşti Formation which occurs in the Abrud area.

\section{GEOLOGICAL SETTING}

The investigated section is located in the southern part of Abrud area (Southern Apuseni Mountains), on the left side of the Cerbului Valley (Bucium Cerbu locality) (Fig. 1). The studied deposits belong to the Căbeşti Formation. This formation was described by Ghițulescu and Socolescu (1941) as olistostromes with sandstones and quartzitic clays within flysch deposits.

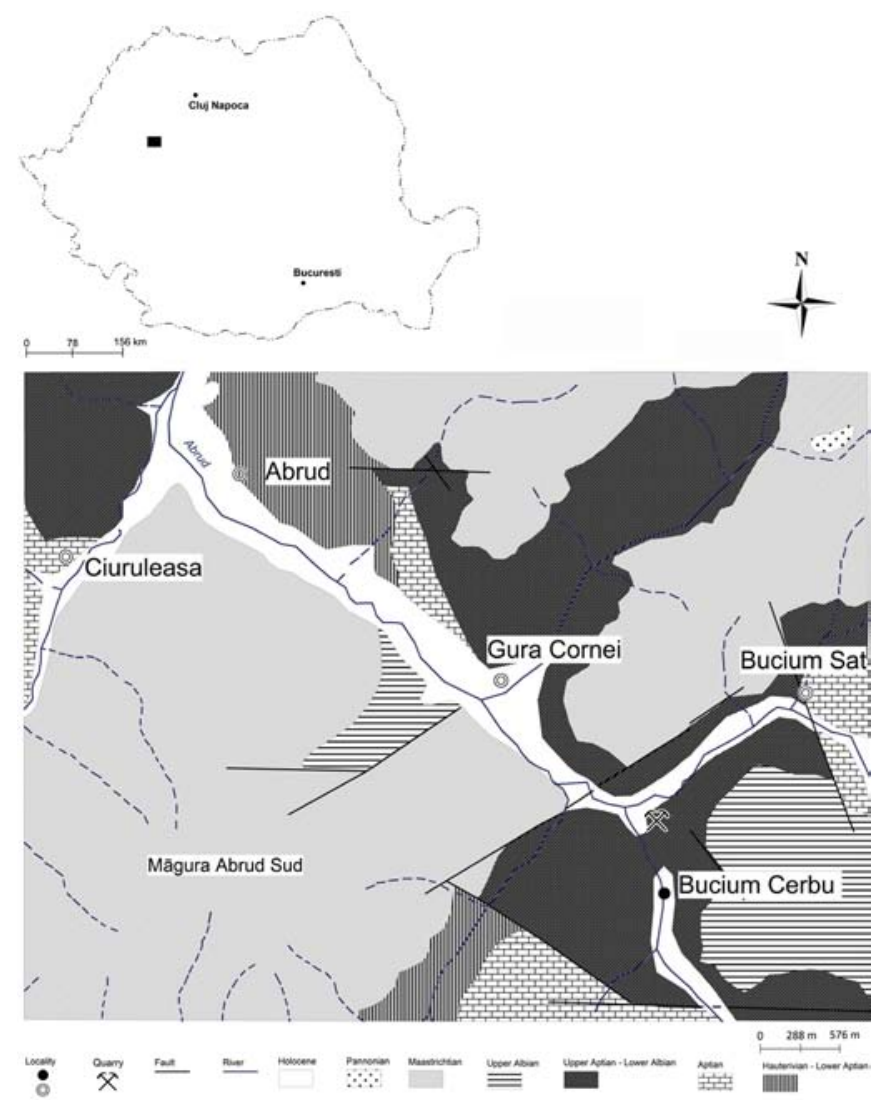

Fig. 1. Location map of the studied section: Bucium Cerbu quarry (sheet Abrud, scale 1: 50.000, after Bordea et al., 1979; modified). 
The deposits of the Căbeşti Formation were assigned by Bordea et al. (1979) to Soharu Formation (grey clayey flysch deposits with sandstone and carbonate sequences, and rare wildflysch episodes). The Soharu Formation is present in the lower part of "Valea Povernei Beds" (with sandstonecarbonate schistose flysch), respectively "Pârâul Izvorului Beds" (with sandstone schistose flysch) in the upper part. The Căbeşti Formation belongs to the Căbeşti Nappe (Lupu et al. in Bleahu et al., 1981), and it was reported by Balintoni (2003) as part of the Austrian Transylvanides. A thick succession (about 15 meters) of the Căbeşti Formation crops out in the Bucium Cerbu quarry, consisting of rhtmically interbedded marls and sandstones (Fig. 2). Ilie (1953) described the Bucium Cerbu deposits as white limy marls and grey-greenish and violet calcareous marls.

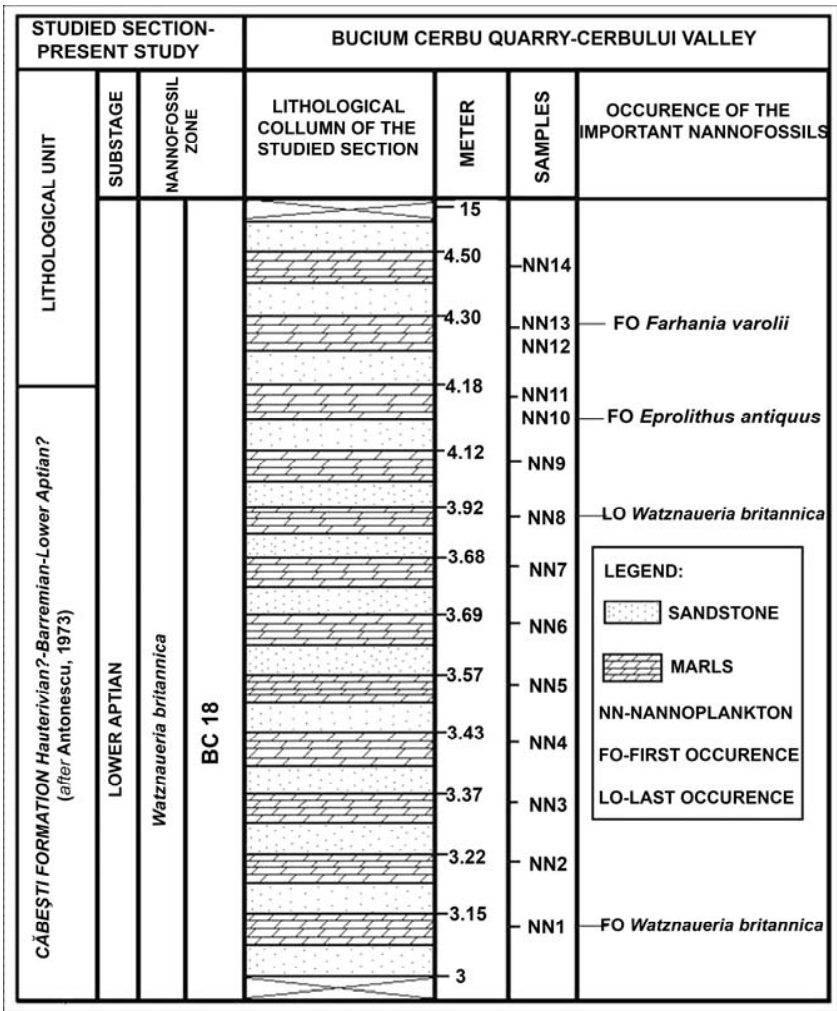

Fig. 2. Lithology of the studied sections from Southern Apuseni Mts. Main nannofossil events are marked with FO and LO.

\section{METHODS AND MATERIAL}

For quantitative and qualitative analysis, smear slides of 14 samples (prepared using the method described by Thierstein et al. as reported by Negri, 1988) were examined under an Axiolab Zeiss light microscope at $1000 \mathrm{X}$ magnification. Sampling was performed each $20 \mathrm{~cm}$.

Concerning the quantitative study, the most representative samples are located in the middle part of the studied successions. The listed calcareous nannofossils are indexed according to Perch-Nielsen (1985), respectively Bown \& Young (1998). The individual abundances for each species were counted according to the classification proposed by Bown et al. (1998) as follows: R-rare specimens used where one or several specimens were recorded outside of the 300 specimen standard count and they represent $<1 \%$ of the assemblages, F-frequent/few (1-5 specimens, about cca. $1 \%$ of the assemblages/ <one field of view), C-common (6-60 specimens, $2-20 \%$ of the assemblages/ $>$ one field of view), and A-abundant $(>60$ specimens which represent $>20 \%$ of the assemblages/ $>10$ field of view.

\section{RESULTS}

In the studied samples from the Bucium Cerbu quarry, more than 50 species of calcareous nannofossils were identified. Tethyan nannofossils (e.g., Calcicalathina oblongata, Tubodiscus jurapelagicus) common in low to middle latitudes (e.g., Diazomatolithus lehmanii, Cruciellipsis cuvillierii, Speetonia colligata, Conusphaera mexicana, Watznaueria barnesiae, Zeugrhabdotus embergeri), as well as Boreal species (e.g., Kokia borealis, K. stelatta, Eprolithus antiquus) were identified (Fig. 3).

The presence of species Watznaueria britannica and the common re-appearance of this taxon in the section from Bucium Cerbu quarry point to the BC18 Biozone. According to Bown et al. (1998), the BC18 Zone is defined between the first occurrence (FO) of Rhagodiscus gallageri and/or by the re-entry of frequent Watznaueria britannica up to the FO of Farhania varolli; this biozone is Early Aptian in age. For the BC18 Biozone. Within the Early Aptian nannofloras, common Valanginian reworked nannofossils were observed. Such taxa are Nannoconus st. minor (with the last occurrence - LO in Valanginian, after Perch-Nielsen 1985; Bralower, 1991; Bergen, 1994; Mutterlose, 1996; Bown et al., 1998), Tubodiscus jurapalegicus (LO placed in Valangianian, according to Bralower et al., 1989; Erba, 1994, 2004; Melinte and Mutterlose, 2001), Eprolithus antiquus and Speetonia colligata (with LO in Hauterivian, after Perch-Nielsen, 1985; Bralower et al., 1989; Bralower, 1991; Bergen, 1994; Erba, 1994, 2004; Bown et al., 1998; Melinte and Mutterlose, 2001), Cruciellipsis cuvillierii (with LO in the early Late Hauterivian, after Perch-Nielsen, 1985; Bralower, 1991; Bergen, 1994; Mutterlose, 1996), and Assipetra terebrodentarius (FO in the Hauterivian/Barremian boundary interval, after Bergen, 1994 and Bown et al., 1998).

The presence of species like Calcicalathina oblongata, Speetonia colligata, Conusphaera mexicana and Nannoconus steinmanii was remarked and correspond to the NK3A Calcareous Nannofossil Subzone (Bralower et al., 1989), respectively late Early Valanginian-early Late Valanginian (Melinte and Mutterlose, 2001).

The presence of mixed nannofossils with different palaeobiogeographical affinities may reflect major water masses exchange between the Tethyan and the Boreal Domains, during the Lower Cretaceous in the Southern Apuseni Mountains

We also identified some Boreal species (e.g. Kokia borealis, K. stellata) reworked from older deposits. Species like Kokia borealis characterized Valanginian and partially Ryazanian deposits, Bown et al. (1998). The rare presence of nannoconids in the identified in situ nannofloras could be indicative for the "nannoconids crisis" (Early Aptian) described by Erba (1994). The dominant nannofossils in the studied assemblages are Diazomatolithus lehmanii and Watznaueria barnesiae ( $>20 \%$ of the assemblages).

The listed species reflects high fertility of the surface waters, richness in nutrients. 

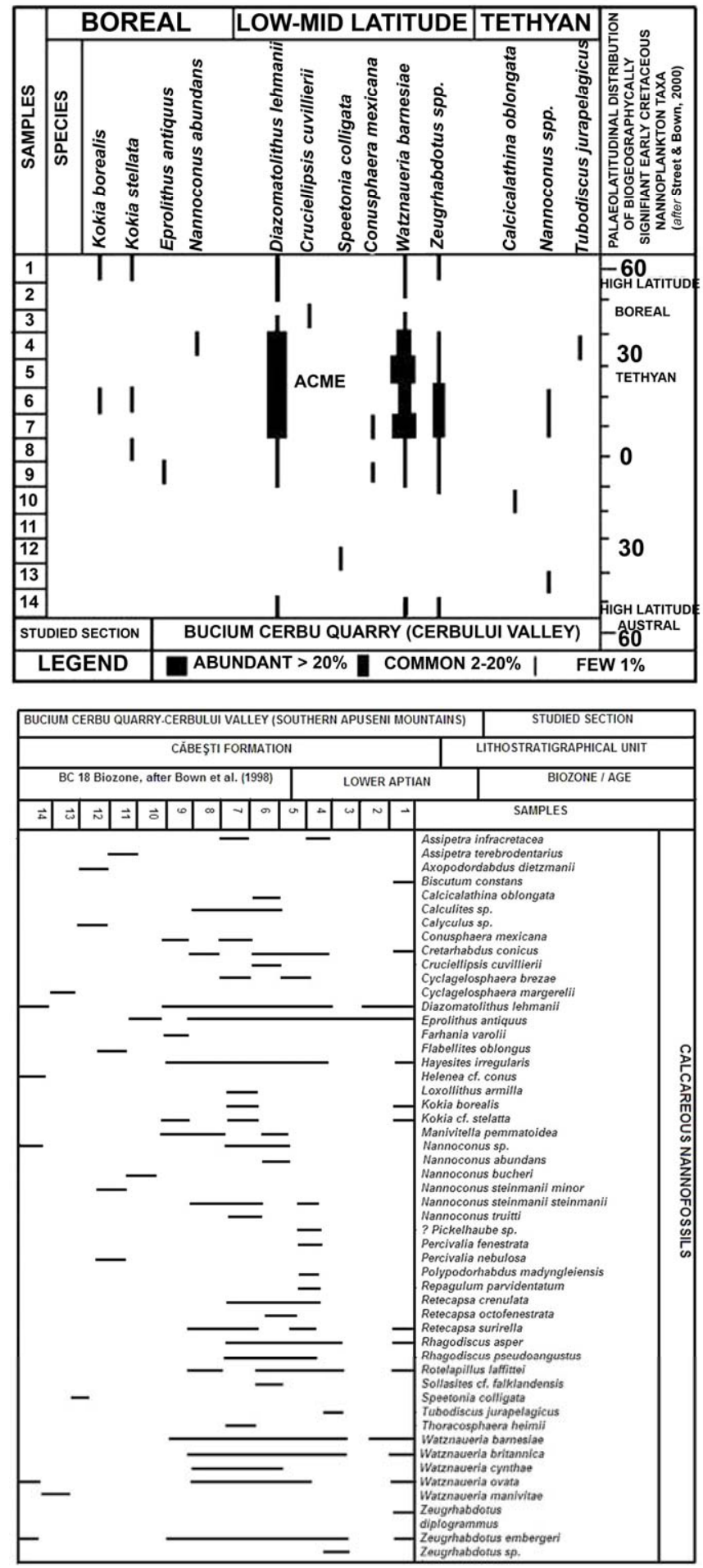

Fig. 3. Distribution of calcareous nannofossils in the studied section.

\section{DISCUSSION}

Lower Cretaceous calcareous nannofossils are represented by common species (e.g., Watznaueria barnesiae, $W$. fossacincta, Micrantholithus obtusus, M. hoschulzii, Rhagodiscus asper, Diazomatolithus lehmanii) and simple muroliths (e.g., Zeugrhabdotus, Staurolithities) (Bown et al. 1998). Common taxa identified in the present study are Diazomatolithus lehmanii, and species belonging to the genera Rhagodiscus ( $R$. asper, R. pseudoangustus), Watznaueria and Zeugrhabdotus. The species $W$. barnesiae is recognized as a cosmopolitan species, resistant to diagenesis (Mutterlose and Kessels, 2000; Roth and Bowdler, 1981; Premoli Silva et al., 1989). Concerning the high abundance of Watznaueria barnesiae, some authors assume that it indicates low surface water fertility (Herrle et al., 2003), or by contrary eutrophic environments and high nutrient supply (Lees et al. 2004). During the Early Aptian, according to Erba (1994), boreal species disappeared and a decline of nannoconids was recognized at global level. From palaeoecological point of view, Nannoconus has been interpreted as being restricted to the lower photic zone (Erba, 1994; Coccioni et al., 1992, Bersezio et al., 2002), related to oligotrophic palaeoenvironments and warm surface waters (Perch-Nielsen, 1979; Erba, 1994; Aguado et al., 2000) with distribution in epicontinental basins (Busson and Nöel, 1991). The rare presence of the nannoconids and a dominance of Diazomatolithus lehmanii in the studied section probably reflects biotic changes which characterized the Aptian interval. Otherwise, the abundance of Diazomatolithus lehmanii has significantly increased in several Cretaceous intervals (i.e., across the "Valanginian Weissert oceanic anoxic Event", accompanying biotic change and global perturbation of marine ecosystems in the Tethys Realm - Bersezio et al., 2002; Erba et al., 2004). Cretaceous calcareous nannofossil assemblages show significant differences in abundance and diversity between the Boreal, the Tethyan and the Indo-Pacific area, with clear different palaeobiogeographical distribution patterns for the Berriasian-Barremian and Aptian-Albian intervals (Mutterlose, 1992; Melinte ad Mutterlose, 2001). According to Mutterlose et al. (2003) high latitudinal nannofossil assemblages are often quite different from those of low to middle latitudes, and consequently show, at least in the Early Cretaceous a significant provincialism.

Sediments of Early Cretaceous age present a large distribution in the orogenic areas of the Romanian Carpathians and in the stable platforms (Moldavian Platform, Moesian Platform). These sediments contain nannofloral assemblages, dominated by Tethyan taxa, but also frequent cosmopolitan nannofossils occur. Certain intervals (as the Late Valanginain and the Barremian-Aptian boundary interval) contain also a few Boreal species (Melinte and Mutterlose, 2001; Avram and Melinte, 1998). Tethyan calcareous nannofossil assemblages of Early Berriasian-Late Hauterivian age were identified on the Romanian territory by Melinte (1991), respectively in the Southern Apuseni Mountains (present study). Calcareous taxa common for the Early Valangianian were identified in the Carhaga Formation and Svinița region by Melinte (1992) and Avram et al. (1998). The Berriasian-Valanginian interval from the Carpathians and the Moesian Platform was described by Melinte (1997) as one of mixed cosmopolitan, tethyan and boreal taxa (especially in the Late Valanginian). For the Romanian Carpathians, sediments of Valanginian age with boreal flora and fauna which immigrated in the Tethyan Realm were described by Melinte and Mutterlose (2001). Pelitic rocks of Late Berriasian-Early Aptian age were described by Avram et al. (1998) in the Crivina marls from Reşița-Moldova area, respectively calcareous nannofossil assemblages of Barremian-Aptian age in the Muierii Valley (Dâmbovicioara area) which contain mixed Tethyan and Boreal nannofloras (Barragán \& Melinte, 2006). In the Southern Apuseni Mountains, deposits with calcareous nannofossils of Aptian-Albian age were described by Chira et al. (2004) and Vulc et al. (2006). 


\section{CONCLUSIONS}

A qualitative and quantitative study of the calcareous nannofossils from Bucium Cerbu quarry (Southern Apuseni Mountains) has been performed. The calcareous nannofloras is mainly Tethyan. The presence of cosmopolitan and boreal taxa is noticeable. The identified nannofloras are of Early Aptian age; additionally reworked nannofossils of Valanginian age were identified. The data presented herein argue for the presence of mixed Tethyan, Boreal and cosmopolitan nannofloras in the Early Aptian from the Romanian territory (Southern Apuseni Mountains, respectively). Even if we agree that the identified Valanginian taxa are reworked in the nannofloral assemblages, these nannofossils must proceed from subjacent older deposits. This means that also in the Southern Apuseni Mountains the Valanginian "Boreal nannoplankton excursion" as described by Melinte and Mutterlose (2001) is present. Quantitatively, the dominant species of the assemblages are Diazomatolithus lehmanii and Watznaueria barnesiae, which probably reflect eutrophic environments and a high fertility of surface water masses.

Acknowledgements. This work is a contribution to the Grant 18/420 funded by the National Council of Research and Science C.N.C.S.I.S. Romania. The author is grateful to Dr. Mihaela Carmen Melinte (National Institute of Marine Geology and Geo-ecology-GeoEcoMar Bucharest) and Dr. Stjepan Coric (Geological Survey of Austria) for critical reviews which greatly improved the manuscript, suggestions and comments, respectively to Dr. Dana Pop, who kindly reviewed the English version of this manuscript.

\section{APPENDIX}

\section{Calcareous nannofossils:}

Assipetra infracretaceae (Thierstein, 1973) Roth, 1973

A. terebrodentarius (Appelgate et al. in Covington \& Wise, 1987) Rutledge \& Bergen in Bergen, 1994

Axopodorhabdus dietzmanii (Reinhardt, 1965) Wind \& Wise in Wise \& Wind, 1983

Biscutum constans (Górka, 1957) Black in Black \& Barnes, 1959

Calculites sp. Prins \& Sissigh \& Sissing, 1977

Calyculus sp. Nöel, 1973

Conusphaera mexicana Trejo, 1969

Cretarhabdus conicus Bramlette \& Martini, 1964

Cruciellipsis cuvillieri (Manivit, 1966) Thierstein, 1971 emend. Wind \& Cepek, 1979

Cyclagelosphaera brezae Applegate \& Bergen, 1998

C. margerelii Nöel, 1965

Diazomatolithus lehmanii Nöel, 1965

Eprolithus antiquus Perch-Nielsen, 1979

Farhania cf. varolii Varol, 1992

Flabellites oblongus (Bukry, 1969) Crux, 1982

Hayesites irregularis Manivit, 1971 emend. Applegate et al. in Covington \& Wise, 1987

Helenea cf. conus Worsley, 1971

Loxolithus armilla (Black in Black \& Barnes, 1959) Nöel, 1965

Kokia borealis Perch-Nielsen, 1988

K. cf. stellata Perch-Nielsen, 1988

Manivitella pemmatoidea (Deflandre in Manivit, 1965) Thierstein, 1971
Nannoconus Kamptner, 1931

N. abundans Stradner \& Grün, 1973

N. bucheri Brönnimann, 1955

N. steinmannii Lamptner, 1931 ssp. minor Deres \& Archéritéguy, 1980

N. steinmannii steinmannii Kamptner, 1931

N. truitti Brönnimann, 1955

? Pickelhaube sp. (Roth, 1983) Applegate et al. in Covington \& Wise, 1987

Percivalia fenestrata (Worsey, 1971) Wise, 1983

P. nebulosa Bukry, 1969

Polypodorhabdus madyngleiensis Black, 1971

Repagulum parvidentatum (Deflandre, 1954) Forcheimer, 1972

Retecapsa crenulata (Bramlette and Martini, 1964) Grün, 1975

R. octofenestrata (Bralower, 1989) Bown, 1998

R. surirella (Deflandre and Fert, 1954) Grün in Grün \& Allemann, 1975

Rhagodiscus asper (Stradner, 1963) Reinhardt, 1967

R. pseudoangustus Crux, 1987

Rotelapillus laffittei (Nöel, 1957) Nöel, 1973

Sollasites cf. falkladensis Filewicz et al., in Wind \& Wise, 1977

Speetonia colligata Black, 1971

Tubodiscus jurapelagicus (Worsley, 1971) Roth,1973

Watznaueria barnesiae (Black in Black \& Barnes, 1959)

Perch-Nielsen,1968

W. britannica (Stradner, 1963) Reinhardt, 1964

W. cynthae Worsley, 1971

W. "ovata"' Bukry, 1969

W. manivitae (Forcheimer, 1972) Bukry, 1973

Zeugrhabdotus Reinhardt, 1965

Z. diplogrammus (Deflandre in Fert \& Fert,1954) Burnett in Gale et al. (1996)

Z. embergeri (Nöel,1959) Perch-Nielsen,1984

Calcareous dinoflagellates :

Thoracosphaera heimii Lohmann (1919) Kamptner, 1941

\section{R E F E R E N C E S}

Aguado, R., Company, M. \& Tavera, M. 2000, The Berriasian/Valanginian boundary in the Mediterranean region: new data from the Caravaca and Cehegin sections, SE Spain. Cretaceous Research, 21: 1-21.

Antonescu, E. 1973, Asociații palinologice caracteristice unor formațiuni cretacice din Munții Metaliferi. Dări de Seamă ale Institutului Geologic, LIX, 3: 115-169

Avram, E., Melinte, M. 1998, Barremian-Aptian boundary in the Dâmbovicioara area (Romanian Carpathians). Zentralblatt für Geologie und Paläontologie, Teil I, 1112: 117-129.

Avram, E., Turculeț, I. \& Melinte, M.C. 1998, Boreal immigrants into the Valanginian succesion of the Romanian Carpathians. Romanian Journal Stratigraphy, 77: $27-35$

Balintoni, I. 2003, Short outlook on the structure of the Apuseni Mountains. Field Trip Guide, $4^{\text {th }}$ Regional IFAA Meeting IFAA: 9-17.

Barragán, R., Melinte, M.C., 2006, Palaeoenvironmental and palaeobiological changes across the BarremianAptian boundary interval in the Tethys Realm (Mexico and Romania). Cretaceous Research, 27 (4): 521-541. 
Bergen, J.A. 1994, Berriasian to early Aptian calcareous nannofossls from the Vocontian Trough (SE France) and Deep Sea Drilling Site 534: new nannofossil taxa and a summary of low-latitude biostratigraphic events. Journal of Nannoplankton Research, 16: 59-69.

Bersezio, R., Erba, E., Gorza, M. \& Riva, A. 2002, Berriasian-Aptian black shales of the Maiolica Formation (Lombardian Basin, Southern Alps, Northern Italy): local to global events. Palaeogeography, Palaeoclimatology, Palaeoecology, 180: 253-275.

Bleahu, M., Lupu, M., Patrulius, D., Bordea, S., Ştefan, A. \& Panin, S. 1981, The Structure of the Apuseni Mountains. Carpato Balkanic Geological Association, XII Congress, Guide to Excursion. $\mathrm{B}_{3}, 23$, Institutul de Geologie şi Geofizică, Bucureşti, p. 107.

Bordea, S., Avram, E. \& Bordea, J. 1979, Harta geologică a României, scara 1:50.000, foaia Abrud. Institutul de Geologie şi Geofizică, Bucureşti.

Bown, P.R., Young, J.R. 1998, Techniques. In Calcareous Nannofossil Biostratigraphy (Bown P.R., Ed.), British Micropalaeontology Society Series. Chapman \& Hall, p. 16-28.

Bown, P.R., Rutledge, D.C., Crux, J.A. \& Gallagher, L.T. 1998, Lower Cretaceous. I In Calcareous Nannofossil Biostratigraphy (Bown P.R., Ed.), British Micropalaeontology Society Series. Chapman \& Hall, p. 86-131.

Bralower, T.J., Monechi, S. \& Thierstein, H.R., 1989. Calcareous nannofossil zonation of the JurassicCretaceous Boundary Interval and Correlation with the Geomagnetic Polarity Timescale. Marine Micropaleontology, 14: 153-235.

Bralower, T.J., 1991. Lower Cretaceous calcareous nannofossil biostratigraphy of a North Sea borehole: implications for Boreal Cretaceous stratigraphy. Proceedings of the Yorkshire Geological Society, 48: 421-434.

Busson, G., Nöel, D. 1991, Les nannoconidés, indicateurs environmentaux des océan et mers épicontinentales du Jurassique terminal et du Crétacé inférieur. Oceanology Acta, 14: 333-356.

Chira, C., Bălc, R. \& Vulc, A.-M. 2004, Cretaceous calcareous nannofossils from Ceru Băcăinți area, Apuseni Mountains, Romania. Acta Paleontologica Romaniae, IV: 89-96.

Coccioni, R., Erba, E. \& Premoli Silva, I. 1992, BarremianAptian calcareous plankton biostratigraphy from the Gorgo Cerbara section (Marche, central Italy) and implications for plankton evolution. Cretaceous Research, 13: 517-537.

Erba, E. 1994, Nannofossils and superplumes: The Early Aptian nannoconid crisis. Paleogeography, 9: 483-501.

Erba, E., 2004. Calcareous nannofossils and Mesozoic oceanic anoxic events. Marine Micropaleontology, 52: 85-106.

Erba, E., Bartolini, A. \& Larson Roger, L. 2004, Valanginian Weissert oceanic anoxic event. Geological Society of America, 32 (2): 149-152.

Filtsch, E. 1857. Reise in das siebenbürgischen Erzgebirges. Verhandlung die Siebenburgischen Naturwissenschaft. VIII, Hermannstadt.

Ghițulescu, T., Socolescu, M. 1941, Étude géologique et minière des Monts Métallifères. Anuarul Institutului Geologic al României, XXI: 181-308.
Herrle, J.O., Pross, J., Friedrich, Ch. \& Hemleben, C. 2003, Short-term environmental changes in the Cretaceous Tethyan Ocean: micropaleontological evidence from the Early Albian Oceanic Anoxic Event 1b. Terra Nova, 15 (1): 14-19.

Ianovici, V., Giuşcă, D., Ghiţulescu, T.P., Borcoş, M., Lupu, M. \& Bleahu, M. 1969, Evoluția geologică a Munților Metaliferi. Editura Academiei Române, 741 p.

Ilie, M. 1953, Structura geologică a depresiunii Abrud. Anuarul Comitetului Geologic, XXV: 40-117.

Lees, J.A., Bown, P.R., Young, J.R. \& Riding J.B., 2004, Evidence for annual records of phytoplankton productivity in the Kimmeridgian Clay Formation coccolith stone bands (Upper Jurassic, Dorset, UK). Marine Micropaleontology, 52: 29-49.

Melinte, M.C. 1991, Late Jurassic-Early Cretaceous nannoplankton biostratigraphy of Southern Carpathians (Romania). International Nannoplankton Association, 13 (2): 57-58.

Melinte, M.C. 1992, Calcareous nannoflora from the Jurassic-Cretaceous boundary interval from the Perşani Mountains (Carhaga Formation). Studii şi Cercetări Geologice, 37: 83-87.

Melinte, M.C. 1997, Tethyan and Boreal nannoflora around the Jurassic-Cretaceous boundary in Romania. Acta Palaeontologica Romaniae, 1: 234-240.

Melinte, C.M., Mutterlose, J. 2001, A Valanginian (Early Cretaceous) 'boreal nannoplankton excursion' in sections from Romania. Marine Micropaleontology, 43: 1-25.

Mutterlose, J. 1992, Biostratigraphy and paleogeography of Early Cretaceous calcareous nannofossils. Cretaceous Research, 13: 167-189.

Mutterlose, J. 1996, Calcareous nannofossil palaeoceanography of the Early Cretaceous of NW Europe. Mitteilungen aus dem GeologishPaläontologishen Institut der Universität Hamburg, 77: 291-313.

Mutterlose, J., Kessels, K. 2000, Nutrient cycles and black shales from the Jurassic/Cretaceous boundary interval of the Russian Platform. Journal of Nannoplankton Research, Abstract, 22 (2): 127.

Mutterlose, J., Bornemann, A., Luppold, F.W., Owen, H.G., Ruffell, A., Wiiss, W. \& Wray, D. 2003, The Vöhrum section (northwest Germany) and the Aptian/Albian boundary. Cretaceous Research, 24: 203-252.

Mücke, K. 1915, Beitrag zur kenntnis des Karpathensandsteins im Siebenburgisches Erzgebirge. Verhandlung die Siebenburgischen Naturwissenschaft, Wien.

Negri, A. 1988, Biostratigrafia a nannofossili calcarei del miocene inferiore-medio Italiano e Mediterraneo. Dottorato di Ricerca in Paleontologia, Modena-Bologna, Firenze-Roma, $289 \mathrm{p}$.

Pálfy, M. 1902, Die oberen Kreideschichten in der Umgebung von Alvincz. Mitteilung die Geologische Jahrsbuch. XIII: 21-27.

Perch-Nielsen, K. 1985, Mezozoic calcareous nannofossils. In: Bolli, H. M., Saunders, J. B., Perch-Nielsen, K. (Eds.), Plankton Stratigraphy, Cambridge University Press, Cambridge , p. 329-427Premoli Silva, I., Erba, E. \& Tornaghi, M.E. 1989, Paleoenvironmental signals and changes in surface fertility in mid-Cretaceous $\mathrm{C}_{\text {org }}$ - rich pelagic facies of the fucoid marls (central Italy). Geobios, 11: 225-236.

Studia UBB, Geologia, 2008, 53 (2), 5 - 11 
Roth, P.H., and Bowdler, J., 1981. Middle Cretaceous calcareous nannoplankton biogeography and oceanography of the Atlantic Ocean. In The Deep Sea Drilling Project: A Decade of Progress (Warme, J.E., Douglas, R.G. \& Winterer, E.L., Eds.), Special Publication of the Society of Economic Paleontologists and Mineralogists, 32: 517-546.
Vulc, A.-M., Chira, C. \& Igrițan, A. 2006, Lower Cretaceous (Apțian-Albian) calcareous nannofossil assemblages from the Southern Apuseni Mountains, Romania. $11^{\text {th }}$ Biennial Conference on the International Nannoplankton Association (INA), Lincoln (Nebraska, SUA), p. 111-112.

\section{PLATE 1}

Light Microscope, $\mathrm{N}+$. Scale bar is valid for all figures.

Calcareous Nannofossils

Fig. 1. Calculites sp., sample 6, 7, 8.

Fig. 2. Flabellites oblongus, sample 12.

Fig. 3. Rhagodiscus asper, sample 4, 5, 6, 7 .

Fig. 4. Axopodorhabdus dietzmanii, sample 12.

Fig. 5. Rhagodiscus asper, sample 12.

Fig. 6a, b. Watznaueria britannica, sample 1, 2, 4, 5, 6, 7, 8 .

Fig. 7. Cyclagelosphaera brezae, sample 5, 7 .

Fig. 8. Helenea cf. conus, sample 14.

Fig. 9. Watznaueria barnesiae, sample 1, 2, 4, 5, 6, 7, 8, 9, 13.

Fig. 10. Polypodorhabdus madyngleiensis, sample 5 .

Fig. 11. Hayesites irregularis, sample 1, 4, 5, 6, 7, 8, 9.

Fig. 12. Percivalia nebulosa, sample 10.

Fig. 13. Zeugrhabdotus embergeri, sample 1, 4, 5, 6, 7, 8, 9, 13.

Fig. 14. Biscutum constans, sample 1.

Fig. 15. Nannoconus steinmannii steinmannii, sample 2, 6, 7.

Figs. 16-19. Nannoconus sp., sample 6, 7, 14.

Fig. 17. Nannoconus steinmanii minor, sample 12.

Fig. 20. Kokia borealis, sample 1, 6.

Fig. 21. Kokia cf. stellata, sample 1, 6,8.

Fig. 22. Eprolithus antiquus, sample 10.

Fig. 23. Assipetra terebrodentarius, sample 11, 14.

Fig. 24. Diazomatolithus lehmanii, sample 1, 2, 4, 5, 6, 7, 8, 9, 14.

Fig. 25. Rotelapillus laffittei, sample 1, 4, 5, 6, 8.

Fig. 26. Tubodiscus jurapelagicus, sample 4 .

Fig. 27. Assipetra infracretacea, sample 4,7.

Fig. 28. Conusphaera mexicana, sample 7, 9.

Fig. 29. Farhania cf. varolii, sample 9.

Studia UBB, Geologia, 2008, 53 (2), 5 - 11 

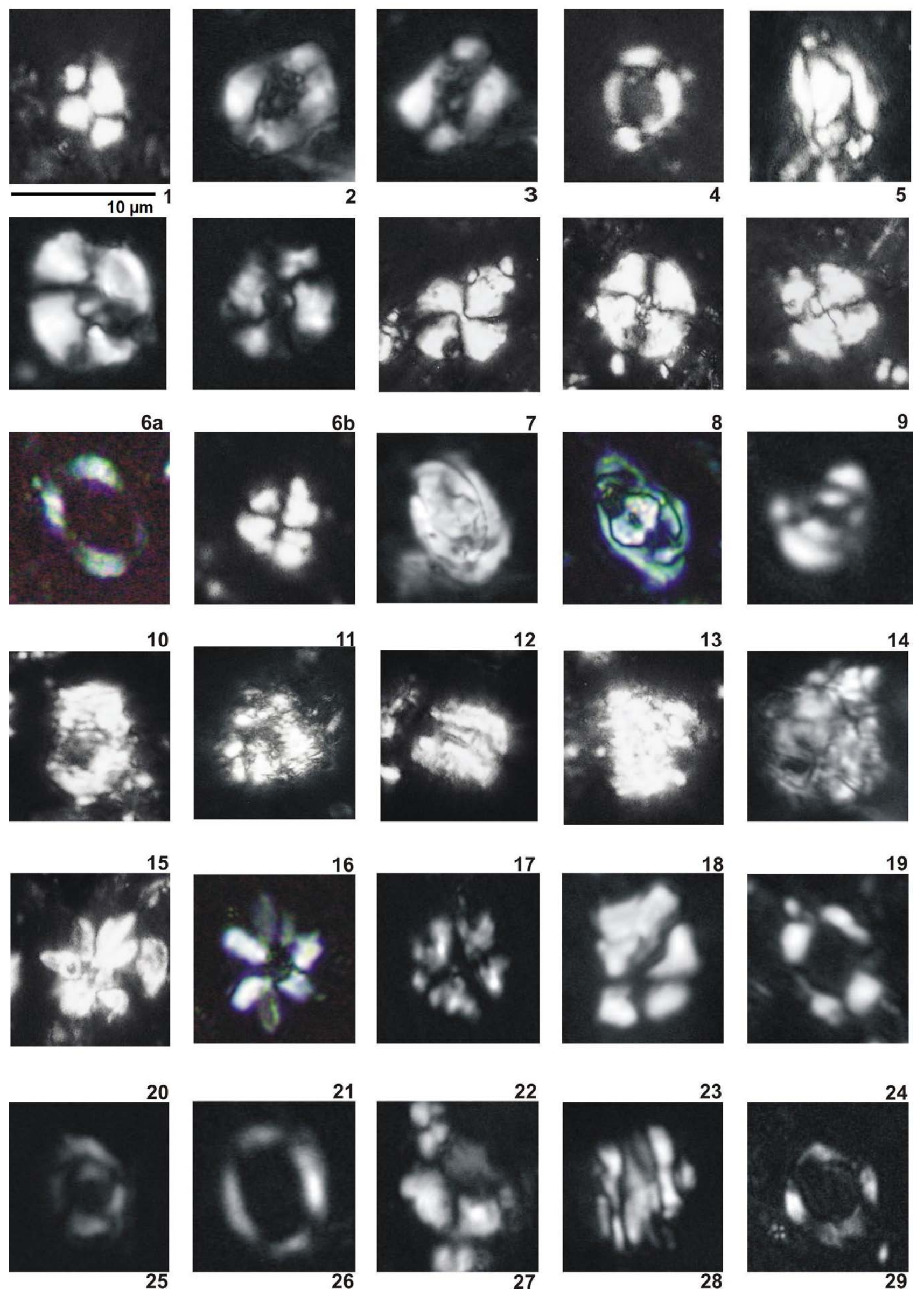